\title{
A CHRISTIAN RESPONSE TO SHANKARA'S DOCTRINE OF NON-DUALITY
}

\author{
Muriwali Yanto Matalu \\ Gerakan Kebangunan Kristen Reformed (GKKR) \& \\ Gereja-Gereja Reformasi di Indonesia (GGRI) \\ Korespondensi: muryto@yahoo.co.id
}

Diajukan: 28-Aug-2017; Direview: 26-Sep-2017; Diterima: 14-Okt-2017; Direvisi: 19-Okt-2017

\begin{abstract}
This article describes Shankara's doctrine of non-duality and makes a Christian response. Dealing with the thought of this Indian great Philosopher is not an exaggerating effort for the concept of nonduality prevails in this New Age era. Terms such as Brahman (the absolute reality), Atman (the absolute basis of human soul which is identical to Brahman), and māya (illusion) are not peculiar to those who are familiar with the teaching of the today's New Age gurus, for instance, Deepak Chopra. Hence, my effort to react through the lens of the Christian faith will be worthwhile particularly to enrich our understanding in the realm of Christian apologetics. Here, my response shows the inherent metaphysical, logical, and ethical problems of Shankara's non-duality which he expounds in concepts like Brahman, Ātman, and māyā.
\end{abstract}

KEYWORDS: Non-duality; Shankara; Brahman; Ātman; māyā; Trinity; Christian apologetics.

ABSTRAK: Artikel ini mendeskripsikan doktrin non-duality Shankara dan memberikan respons dari sisi Kristen. Menggeluti pemikiran dari filsuf besar India ini bukanlah suatu upaya yang berlebihan karena konsep non-duality yang bertahan di era Zaman Baru ini. Beberapa terminologi seperti Brahman (Realitas yang absolut), Átman (basis absolut dari jiwa manusia yang identik dengan Brahman), dan māyā (ilusi) tidaklah unik bagi yang mengenal pengajaran guru Zaman Baru, seperti 
Deepak Chopra. Karenanya, upaya penulis untuk bereaksi melalui lensa iman Kristen akan berfaedah khususnya dalam memperkaya pemahaman kita akan realita apologetika Kristen. Disini, respons penulis menunjukkan problem yang terkandung dalam metafisika, logika dan etika dari non-duality Shankara yang dia kemukakan dalam konsep seperti Brahman, Ātman, dan māyā.

KATA KUNCI: Non-duality; Shankara; Brahman; Ātman; māyā; Tritunggal; Apologetika Kristen.

\section{Introduction}

Shankara is probably the greatest philosopher of Hinduism. He was lived around 788-820 A.D. This is the estimation of Max Muller and others such as Mcdonell, Das Gupta, and Radhakrishnan. ${ }^{1}$ However, this is debatable, because other scholars, for instance, Tapasyananda, argues that he was not Adi Shankara (the original Shankara) but Abhinava Shankara (modern Shankara) who lived around 788-839 A.D. and was born in Chidambaram then became the head of the Shankara math (monastery) at Kanchipuram between 801 and 839. 2 Moreover, Tapasyananda affirms Sri T. S. Narayana Sastri's estimation that Sankara was born in 2593 of Kali era (509 B.C.) and died at the age of 32 in 2625 of Kali era (477 B.C.). ${ }^{3}$ I prevent myself to involve in such polemic because my aim here is to present Shankara's doctrine of non-duality and giving a Christian response.

According to the concept of non-duality, the reality is only one and there is no difference between the phenomena world and the absolute (Brahman). Moreover, the phenomena world which we see and perceive is only an illusion $(m \bar{a} y \bar{a})$.

\footnotetext{
1 Swami Tapasyananda, "Introducton" in Madhava-Vidyaranya, Sankara-DigVijaya: the traditional life Of Sri Sankaracharya, trans. by Swami Tapasyananda (Madras: Sri Ramakrishna Math), Kindle Electronic Edition: Introduction, Location 27. Cf. S. Radhakrishnan, Indian Philosophy, Vol. 2 (New Delhi: Oxford University Press, 2008), 415.

2 Tapasyananda, "Introduction" in Vidyaranya, Sankara-Dig-Vijaya, 27.

3 Ibid.
} 
Indeed, as a great thinker, Shankara has a considerable influence to many Hindu philosophers including Sarvepali Radhakrishnan ${ }^{4}$ and today's Hindu gurus, for instance, Deepak Chopra. ${ }^{5}$ Thus, my effort to deal with Shankara's thought, still has a relevance to our time and context particularly in this New Age era.

The following discussions will start to present Shankara's main teachings such as his concept of Brahman, Ātman, individual soul, personal God and māya in which the non-duality is taught. Afterwards, I will give a Christian response. In that response, I will focus on the doctrine of Brahman-Ätman and the doctrine of māy $\bar{a}$. Finally, a conclusion will close the whole study.

\section{Shankara's Thought}

\section{Brahman, Ātman, and lindividual Soul (Jīva)}

According to Shankara, Brahman (the absolute reality) is identical with Atman (the absolute basis of human soul). Thus, to simplify his doctrine on Brahman and Ätman, people could say that Ätman is Brahman. ${ }^{6}$ However, although the two are identical yet they need a separate discussion because Shankara views Ätman as a purely subjective reality while Brahman is a purely objective reality. ${ }^{7}$ In this section, we try to elaborate his teaching on Brahman then proceeds to Ātman, and afterwards the relation between $\bar{A}$ tman and individual soul (jīva).

Indeed, the concept of Brahman as Supreme Being or absolute reality is taught in the Upanishad. ${ }^{8}$ For instance, the first part of it (Isa -

\footnotetext{
4 The significance of Shankara to Radhakrishnan can be seen in his book "Indian Philosophy" when he defends Shankara's view on ethic. See Radhakrishnan, Indian Philosophy, Vol. 2, 580-92. Additionally, Radhakrishnan was a former president of India and a former professor of philosophy at Oxford University.

5 Chopra's books, God: A Story of Revelation and The book of Secrets: Unlocking the Hidden Dimensions of Your Life at least shows Shankara's influence particularly when Chopra maintains the doctrine of non-duality.

6 Radhakrishnan, Indian Philosophy, 501.

7 Ibid.

8 Upanishad is a part of the Vedas that contains some of the central philosophical concepts in Hinduism.
} 
Upanishad) describes in this way,

that (the invisible absolute) is whole; whole is this (the visible phenomenal); from the Invisible Whole comes forth the visible whole. Though the visible whole has come out from that Invisible Whole, yet the Whole remains unaltered." 9

Paramānanda comments on this verse as follows, the indefinite term "that" is utilized in the Upanishad to denote the Invisible Absolute because there are no names or words which can fully define it. Moreover, according to the true wisdom, the phenomena and the Absolute are inseparable. All existence exists in the Absolute, therefore all manifestation is only a modification of the One Supreme Whole and it remains unaltered. ${ }^{10}$ The verse and the Paramānanda's commentary clearly describe the Upanishad teaching on the non-dualism between the absolute reality and the phenomena world which is a central theme in Shankara's theory of Brahman.

Regarding this non-duality, Shankara argues, "the scripture denies the existence of any other conscious entity apart from the supreme Self, in texts like, 'There is no other witness but Him' (Br. III. vii. 23)"11 Moreover, he says that nothing whatsoever can exist separately from Brahman because anything that has an origin derives its birth from Brahman.12 Also, "An effect is non-different from a cause; and nothing apart from Brahman can exist that is birth-less, because it is definitely stated thus: ' $O$ amiable one, before creation all this was but Brahman, one without a second (Ch. VI. ii. 1).'"13

\footnotetext{
9 Swāmi Paramānanda, The Upanishad: Translated and Commented by Swāmi Paramānanda (Boston: The Vedānta Center, 1919), 25. The words in brackets are added by Paramānanda. 10 Ibid.

11 Sri Shankaracharya, Brahma Sutra Bhasya of Sri Shankaracharya, trans. by Swami Gambhirananda (Kolkata: Swami Mumukshananda, 2004), Kindle Electronic Edition: Chapter Three, Section II, Location 1252.

12 Ibid., Location 1257.

13 Ibid.
} 
What is Brahman? The knowledge on the ultimate Brahman consists of two, namely, higher and lower. ${ }^{14}$ Brahmānubhava (the intuitive realization of Brahman) gives the highest insight into Brahman and the one who has it will explain the nature of Brahman by silence or negative marks. Vidyā (correct knowledge) gives the highest positive conceptual on Brahman by giving it attributes of being, consciousness, and bliss, which are self-sufficient. Avidyā (lower knowledge) utilizes attributes which denotes relation, for instance, creatorship and ruler-ship of the universe. However, for Shankara, even the best definition of Brahman is imperfect. ${ }^{15}$

Furthermore, Shankara states that Brahman has no attributes because, "in all texts which aim at presenting the real nature of Brahman, as for instance in, 'soundless, touch-less, color-less, un-diminishing' (Ka. I. iii. 15), etc., Brahman is presented as devoid of all distinguishing attributes."16 Also, according to him, the text denotes Brahman as the Self which has been described as "not this, not this." 17 The main reason for him why Brahman has no attributes is that a finite man cannot comprehend the infinite Brahman. Suppose one can understand Brahman, the result is either man's understanding must be infinite or Brahman finite. ${ }^{18}$ Moreover, words which are utilized to denote a certain thing designate the thing as associated with a certain genus, act, quality, and mode of relation. In this sense, Brahman has no genus, quality, does not act, and is related to nothing else. ${ }^{19}$ Also, when a negation is used to denote Brahman, for instance, infinite, it is not to be equated with a pure negation of the finite. ${ }^{20}$ Therefore, the theistic (e.g. Christian) ways of speaking on the attributes of God such as via negativa, via causalitatis, and via eminentiae, $^{21}$ have no significance values for Shankara. In spite of his

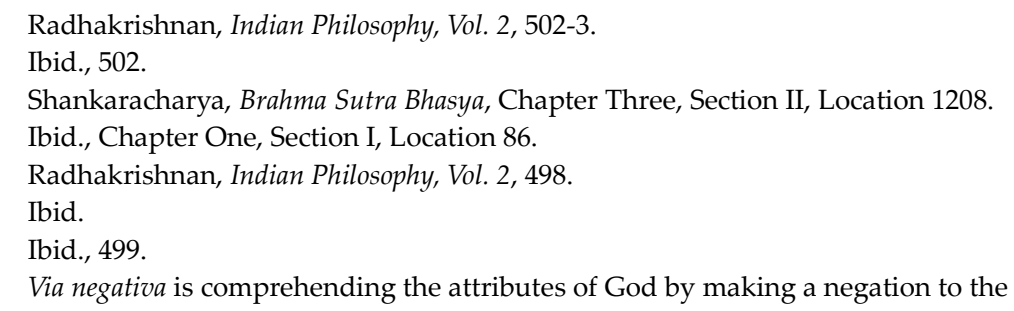


rejection to denote Brahman through giving attributes, in many parts of his Brahma Sutra, he explains it by mentioning some attributes such as omniscient and omnipotent, and that Brahman is the cause of the origin, existence, and dissolution of the universe. ${ }^{22} \mathrm{He}$ also mentions other attributes like immortal, ${ }^{23}$ the basis of all causes and effects, ${ }^{24}$ an independent entity, ${ }^{25}$ it does not decay (eternal) and pervades all (omnipresence), ${ }^{26}$ unchangeable, ${ }^{27}$ etc. He calls Brahman which is explained through giving attributes as saguna Brahman. However, at the same time he maintains Brahman as attribute-less ${ }^{28}$ which he calls nirguna Brahman (see the explanation about saguna and nirguna Brahman in the next section which deals with $\bar{I}_{\text {svara; }}$ the personal God). It is clear here that on the one hand Shankara wants to emphasize Brahman as cannot be known by the limited mind of man, and for this reason the attributes of Brahman cannot be stated because denoting attributes to Brahman will make it finite, yet on the other hand Shankara makes some claims on it in order to explicate its existence. By doing this an avoidable contradiction appears.

What is the relation between Brahman and $\bar{A}$ tman? Shankara argues that $\bar{A}$ tman is equal with Brahman. They have identical characteristic of being, consciousness, all-pervadingness and bliss. ${ }^{29}$ He views Ātman as the true self or the permanent self which is distinct from the object, and argues that the subject (self) opposes the object like light and darkness so

\footnotetext{
attributes of man. For example, man is change then to denote God's attribute people can say that God is changeless (immutable). Via causalitatis is denoting the attributes of God through causality, for instance, God is the Creator of the universe. Via eminentiae is speaking the attributes of God through giving a highest value to what is limited in man, for instance, man's knowledge is limited and hence the knowledge of God is perfect (omniscience).

22 Shankaracharya, Brahma Sutra Bhasya, Chapter One, Section I, Location 60.

23 Ibid., Location 63.

24 Ibid., Location 75.

25 Ibid., Location 101.

26 Ibid., Section III, Location, 359.

27 Ibid., Chapter Three, Section II, Location 1208.

28 Ibid.

29 Radhakrishnan, Indian Philosophy, Vol. 2, 501.
} 
that the true subject never becomes object. ${ }^{30}$ Moreover, the self-existence includes the concept of eternity, immutability, and completeness. The truly real has its being in itself and for itself, consequently asserting the reality of Ātman as the permanent self is asserting the reality of an eternal Brahman (Ātman ca Brahman). ${ }^{31}$ However, Shankara describes that the self cannot be identified with inner feeling goes along with the continual changes of man's mental attitudes, or the empirical "me" which consists of mental contents which develops in time. Even the self-consciousness (ahamakāra) which precedes activity is not the self because it is not antecedent to knowledge and itself becomes an object of knowledge. ${ }^{32}$ We can conclude that Shankara maintains Ātman (permanent self) as not subject to change and flux, consequently it is Brahman itself.

Furthermore, Shankara proposes that intelligence is the true nature of $\bar{A}$ tman; ${ }^{33}$ it is eternal knowledge. ${ }^{34} \mathrm{He}$ also affirms that the consciousness of Ātman which is the cause of the non-conscious is not the finite but the ultimate consciousness. Therefore, this fundamental consciousness as the basis for all reality cannot be confused with the human consciousness. ${ }^{35}$ According to him, Âtman has its own consciousness although there is no object; it is merely light, clear radiance, and the foundation of all human knowledge as well as the light of all human seeing, yet it should not to be confused with logical apprehension which becomes an effect of the interaction between subject and object. ${ }^{36}$ Activity cannot be applied to Átman because activity according to its nature is not eternal. ${ }^{37}$ Also, Átman has no plurality and particularization and therefore all human kind can live and share this universal life. Mankind could think because they share the universal thought, and their

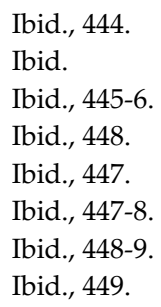


experience is feasible because Atman is in them. ${ }^{38}$ In the following, the relation between Ätman and the individual self will be explained.

Radhakrishnan describes that the purpose of the Vedanta is to lead man from a study on the human self to the reality of the one absolute self (Ätman-Brahman). Furthermore, he defines the individual self as "a system of memories and associations, desires and dislikes, of preferences and purposes." 39 This system has two aspects, first, the vijñanāatman which is changeable, and second, paramätman which is unchangeable. ${ }^{40}$ Shankara distinguishes carefully between the self that is implied in all experiences and the self which is an observed fact of introspection; or between the metaphysical subject (the "I") and the psychological subject (the "me"; empirical self). ${ }^{41}$ According to him, the empirical self is the agent of all activities, therefore he denies activities as being the essential nature of the soul. ${ }^{42}$ Moreover, the difference characteristics (personality) of individual soul is about its connection with buddhi (understanding) which still exists as long as man have not yet gain true knowledge or attainment of freedom (moksa). ${ }^{43}$ We can say that Shankara sees the individuality (personality) in men just exist temporary before they obtain the true knowledge.

Speaking on the activity of the soul, it "depends on the quality of the uphādis (limitation) being ascribed to it and not to its own nature." 44 Moreover, the individual soul (jiv $a$ ) is subject and object, self and not-self, reality and appearance, and consists of Ätman which is limited or individuated by the object. ${ }^{45}$ In other words, jīva is the Ätman clothed in the limitation. ${ }^{46}$ However, the ground of individuality is not the Átman

\footnotetext{
Ibid., 451.

Ibid., 554.

Ibid.

Ibid., 555.

Ibid.

Ibid., 555.

Ibid.

Ibid.

$46 \quad$ Ibid., 557.
} 
on the limitation but in moral determination which is a block of knowledge (vidyā), works (karma), and experience (prajnā $).{ }^{47}$

Indeed, the relation between Ātman-Brahman and the individual soul as have been described above is very complex. In short one can say that: 1) Brahman is the objective ultimate reality of the universe which becomes the ground of everything. 2) Atman is identical with Brahman and could be defined as the subjective ultimate reality which becomes the basis of the individual soul. 3) Speaking about the individual soul, it has two aspects, namely, the metaphysical self and the empirical (psychological) self which becomes the agent of all activities. Moreover, individuality (personality) comes from the empirical self and it cease to exist as long as men gain freedom (true knowledge). However, although $\bar{A}$ tman is the ground of the individual soul, but the basis of the individuality (personality) is not Atman but moral determination.

\section{Isvara (the Personal God)}

At the beginning, the words Brahman, Ätman, and Purusha (the person) in Hinduism were used interchangeably to denote the immutability basis of the world which withstands through the phenomenon change. However, in the later Upanishad, it has a theistic tendency to give Purusha a highest place more than Brahman-Ätman in the macrocosm (KathU, 3.10-11; MundU 2.1.2; 3.2.8; SU, 3.7-8), more immanent in the microcosm (KathU, 4.12; MundU, 2.1.9; SU, 3.13), and that the Purusha becomes the inner controller of the macrocosm and the innermost self (soul). The result is that these verses must have a theistic interpretation. ${ }^{48}$ Zaehner describes that Shankara preferred to take his position on what he considers become the great expression of the Upanishad which denotes the absolute identity of the soul with the Absolute: "That art thou" (ChU, 6.9ff); "This Âtman is Brahman" (MāndU, 2); "I am Brahman" (BU, 1.4.10); and "Consciousness is Brahman" (AitU,

\footnotetext{
$47 \quad$ Ibid., 556.

48 R. C. Zaehner, Hinduism (Oxford: Oxford University Press, 1966), 73-4.
} 
5.3). ${ }^{49}$

Regarding the personal Lord (İsvara), it initially appears in the Atharvaveda Samhita which denotes presiding powers and also identifying the original cosmic man (Purusha)..$^{50}$ As has been mentioned that Brahman in Shankara's view is non-personal, and even the individuality in men apparently exist because they have not yet obtained true knowledge or liberation, thus, as long as men have gained true knowledge the individuality will cease to exist. Indeed, in this sense, Shankara rejects the idea of God as has personality.

Nevertheless, it is not all Hindu thinkers hold the same view. For instance, Ramanuja rejects Shankara's view on the non-personality of Brahman by arguing that Shankara's nirguna Brahman is a blank. According to him, it is impossible to know such a Brahman by any means, perception, inference, or scripture. ${ }^{51}$ Radhakrishnan describes Ramanuja's rejection as follows:

If the sources of knowledge are all relative, they cannot tell us of something which transcends experience; if the scriptures are unreal, even so is the Brahman of which they relate. In the ultimate reality called God we have determination, limitation, difference, other-being which is at the same time dissolved, contained and gathered together in the one. ${ }^{52}$

Ramanuja asserts that Brahman has personality. The qualities of being, consciousness, and bliss give Brahman a character and a personality. $\mathrm{He}$ is the supreme personality whereas the individuals are personal in imperfect way. ${ }^{53}$ Although Ramanuja called himself a Vedāntin (a man who follows the teaching of the Vedānta) like Shankara, yet his discrepancy with Shankara is striking. In Shankara's thought, worshipping God or gods is no more than worshipping human itself

49 Ibid., 74.

50 New World Encyclopedia, "Isvara," http://www.newworldencyclopedia.org/entry /Isvara, accessed May 2, 2016.

51 Radhakrishnan, Indian Philosophy, Vol. 2, 638.

52 Ibid.

53 Ibid., 638-9. 
because bhakti (devotion) which is unreal becomes a very inferior substitute for knowledge (jūanna), namely, the realization of the absolute unity. On the contrary, Ramanuja views liberation as no more than the transcendence of time and space which is the birthright of every human soul, that Sāmkhya-Yoga $a^{54}$ describes as an isolation in which the soul will be like God yet has no personal relationship with God. ${ }^{55} \mathrm{He}$ calls this system as viśishtādvaita (non-duality in difference). ${ }^{56} \mathrm{~A}$ more distinct philosopher from Shankara is Madhvā who goes farther than Ramanuja by calling himself a dualist (dvaita). He distinguishes God who is absolute and independent with the human souls which are eternal but subject to God. ${ }^{57}$

Contrary to those views, Shankara argues that Isvara is the determinate (saguna) Brahman assumed as the supreme personality. ${ }^{58}$ Moreover he views the reality of $\bar{I}$ svara not as a self-evident axiom or not a logical truth but it is an empirical proposition which is practically beneficial. 59 According to him, when people say that God has determinations, personality, perfection (guna), it is complicated to understand how these characteristics coexist with the absoluteness (Brahman). ${ }^{60}$ In his view, Brahman has no personality, yet because the human mind is limited then personalizing it in the term of Isvara (the determinate Brahman) is necessary. However, Shankara sees the idea of devotion (bhakti) to Isvara (the personal Lord) as knowledge at a lower level. ${ }^{61}$ Regarding the relation among Brahman, Isvara, and devotion, Flood summarizes Shankara's view like this, "Brahman in its timeless essence as identical with the self, is beyond all predicates and qualities

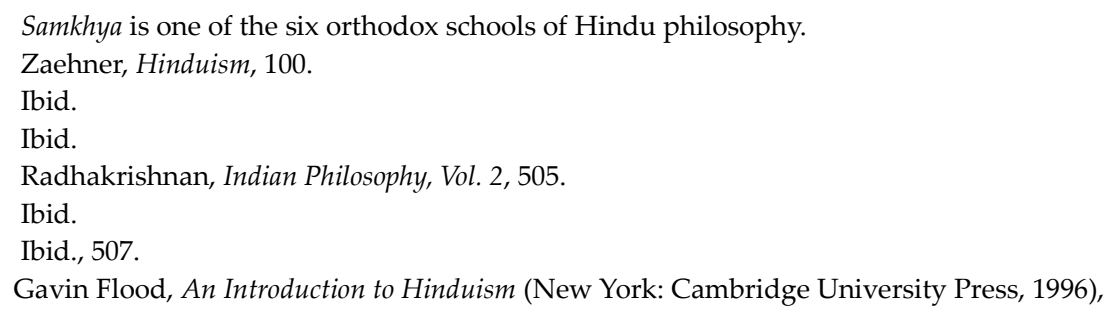


(nirguna), but in its temporal mode as the Lord it has attributes (saguna), and so can be approached through devotion as an object of consciousness." ${ }^{62}$

\section{The Doctrine of Mãyā and the World of Phenomena}

The doctrine of māya emerges as a consequence of Shankara's monistic pantheistic view which asserts reality as one. Thus, he denies duality (or plurality) in the world of phenomena and maintains that it is produced by the limitation of human mind. According to him, the difference between the phenomena world and the true reality (Brahman$\bar{A} t m a n)$ is identical with the distinction between subject and object. All particular facts and events which stand as objects are against the knowing subject. Moreover, while the perceived objects are unreal, the subject (Ätman) which perceives, but it is not itself perceived, is real. ${ }^{63}$ Following Gaudapada (his teacher), Shankara asserts that the objects in both waking and dream as long as they are objects of consciousness are unreal. The world is unreal because it has many self-contradictions while the real is free from all self-contradiction. The phenomena world of time, space, and cause has no self-explanation. Hence, these forms of all experience; time, space, and cause, are not ultimate. ${ }^{64}$ The real must be eternally present, yet we see that the world of experience is not present at all times and consequently it is unreal. ${ }^{65}$

Since the world is unreal, it must come from ignorance (avidya $)$ and illusion $(m \bar{a} y \bar{a})$ which is caused by the superimposition (projection) of what is not the self onto the self. ${ }^{66}$ We have mentioned above that the individual soul has two aspects, namely, the metaphysical self and the empirical (psychological) self which becomes the agent of all activities. Thus, it is clearly here that what Shankara means as a projection of what

\footnotetext{
62 Ibid.

63 Radhakrishnan, Indian Philosophy, Vol. 2, 524.

64 Ibid.

65 Ibid., 525.

66 Flood, An Introduction to Hinduism, 241.
} 
is not the self onto the self (true self) is when the empirical self (the agent of all activities) takes the place of the metaphysical self (A $\bar{A}$ man), then the result is ignorance and illusion. In order to realize the true self which is identical with the absolute, people have to make a discrimination which allows them to distinguish the self from what is not the self, true being from objects, and knowledge from ignorance. ${ }^{67}$

Regarding the relation between Brahman and the world, Shankara argues that both Brahman and the world are identical as well as not identical. They are identical because the world is not apart from Brahman, and they are not identical because Brahman is not subject to the mutation of the world. Indeed, this is somehow a contradiction, and the doctrine of $m \bar{a} y \bar{a}$ tries to solve this problem. It is evident that Shankara is not teaching about two realities or two worlds; the world of Brahman and the world of phenomena. His doctrine of non-duality rejects such view. According to him, because the limitation of the human mind which is bound by ignorance, people only see the appearance of Brahman (the world), and when people see the world as if it is the true reality then the question about the relationship between Brahman and the world emerges. Suppose Brahman is known, all questions about the world will disappear. Suppose people know the nature of the absolute, all finite forms and limits fall away. ${ }^{68}$

Furthermore, speaking that Brahman is the cause of the world cannot be applied because the cause and effect relationship only has meaning in the relation between finite modus of beings. If Brahman is the cause of the world, they must be distinguished and makes Brahman becomes a thing which is related to another thing. ${ }^{69}$ But how can the infinite Brahman becomes finite, for instance, the existence of ignorance and illusion? Indeed, to answer this question, Shankara cannot just simply states that it is because of the ignorance. If that is the answer, one

\footnotetext{
Ibid.

68 Radhakrishnan, Indian Philosophy, Vol. 2, 528.

69 Ibid., 529.
} 
could ask, "If the reality is one, namely, the infinite Brahman, where does this ignorance (a kind of limitation) come from?" Indeed, this is a tough question and on behalf of Shankara, Radhakrishnan argues:

Every attempt to bring Brahman into connection with the world of becoming ends in failure. The relation of the finite world to the infinite spirit is a mystery for human understanding. Every religious system holds that the finite is rooted in the infinite, and there is no breach of continuity between the two, and yet no system till today has logically articulated the relation between the two. ${ }^{70}$

However, Radhakrishnan have made a generalization because the difficulty to see the relation between the infinite and the finite is more a problem of the monistic/ pantheistic (non-dualism) view rather than the theistic. For instance, Christianity makes a clear distinction between God and the universe, and that God is transcendence as well as immanent. We will make a comprehensive response towards this view in the following.

\section{A Christian Response}

The Idea of One Reality (Ātman-Brahman)

Shankara's idea on Brahman, as has been discussed, leaves no place for the absolute difference between God and the universe as taught by the Christian doctrine. This idea rises serious problems in the realm of metaphysic, logic, and moral. The following discussions will briefly expose these problems.

1. Metaphysical problem

In the previous discussion, it has been shown that Shankara has a difficulty to answer the question: Where did the finite things (e.g. illusion itself) come from if there is only one infinite reality (Brahman)? Can the infinite become finite? To avoid this problem, Radakrishnan, on behalf of Shankara, argues that the relation between the finite world and the infinite spirit is a mystery of human understanding. He regards it as also

70 Ibid., 530. 
becomes the difficulty of all religions. Probably we could say that Shankara and other religious traditions are aware of the grandeur and incomprehensibility of the ultimate reality, which tends to go beyond reason. This is a part of the universal religious consciousness. However, even though Christianity affirms that the divine reality is above and beyond human reason or logic, but never contradicts reason or logic.

There are three ideas of the Christian faith which become adequate answers of the problem regarding the relation between the finite and the infinite. First, Christianity maintains the absolute difference between the world and God, for instance, Exodus 20:3-4 presuppose that God has a radical difference with man and things in the world when these verses say, "You shall have no other gods before me. You shall not make for yourself an image in the form of anything in heaven above or on the earth beneath or in the waters below." 71 In the same line 2 Samuel 7:22 describes, "How great you are, Sovereign LORD! There is no one like you, and there is no God but you, as we have heard with our own ears." 72 By stating this absolute difference, Christian faith has no obligation to explain regarding how the infinite becomes finite, because the infinite (God) and the finite (creatures) cannot be confused. To put it another way, in light of the absolute difference between God and the world, it is quite a logical fallacy to say that the infinite can become finite and the finite can become infinite. The doctrine of the incarnation is not speaking about God the infinite becomes man which is finite. It teaches about God (the second Person of the Trinity) who is infinite assumes or takes for himself a human nature and therefore now he has two natures, the first is divine and infinite, and the other is human and finite. In this sense, there is no confusing between the infinite and the finite although they are a unity in the person of Jesus Christ. Hence, the question regarding how the infinite becomes finite is not a matter of Christianity but it is really a problem of Shankara's non-duality, namely, how does the infinite Brahman becomes

$\begin{array}{ll}71 & \text { New International Version. } \\ 72 & \text { Ibid. }\end{array}$ 
finite in the phenomena world if both Brahman and the world is nondifference?

Second, the Bible teaches that God in his good will had created the universe and angels and also created man in his own image. Basically, creation is good and even after God created man he "saw all that he had made, and it was very good"73 (Genesis 1:31). However, men, angels, and the universe who are basically good, have limitation because they are created with (or in) time and space. Augustine prefers to speak on creation with time (cum tempore) rather than in time (in tempore), because creation with time indicates that time is also created by God and its beginning is the same with the beginning of all creation. ${ }^{74}$

Indeed, the Christian doctrine of creation still leaves a mystery, and Berkhof realizes this mystery when he investigates, "How is the transition from a non-creative to a creative state to be reconciled with his [God's] immutability?" To solve this problem, Christian theologians divide God creational act into two aspects, namely, active and passive creation. Active creation denoting God's eternal act in creation and the passive creation denoting its result; the world which is being created which is marked by temporal succession. ${ }^{75}$ In this sense, there is no change in God himself because his creational act is an eternal act and it is only its result, namely, creations (creatures) which are temporal (finite). Furthermore, Christian theologians has understood that the immutability of God primarily concerns with the nature of God, but this does not imply that God cannot act. God is understood as the God who always act (actus purus). At least, through the doctrine of creation, the question about the origin of the finite things has a satisfying answer.

Third, another substantial doctrine to explain the weaknesses of the world - in this respect the existence of evil - is the existence of sin. The Bible maintains that all have sinned and fall short of the glory of God

\footnotetext{
73 Ibid.

74 Cf. Louis Berkhof, Systematic Theology: New Combined Edition (Grand Rapids: Eerdmans, 1996), 130.

75 Ibid., 132.
} 
(Romans 3:23). Also, “ $\ldots$, as by one man sin entered into the world, and death by sin; and so death passed upon all men, for that all have sinned"76 (Romans 5:12). Concerning sin, Christians believe that it is a rebellion against God's authority, order, and law. Berkhof argues that sin is not something passive such as a weakness or an imperfection which cannot be asked for responsibility but an active opposition to God and a positive transgression of his law which constitutes guilt. ${ }^{77}$ And, the consequence of sin is that all things become physically, logically, and morally disorder and deformed, and after all the existence of death (Romans 6:23). In this context, evil is the result of human fall into sin. However, not all evils are sin because the term evil itself could be divided into two aspects, first, nature evils such as earthquake, tsunami, including weaknesses such as disabled people etc., and second, moral evils such as murder, corruption, adultery, etc. ${ }^{78}$ The moral evils are sin while the nature evils are not $\sin ,{ }^{79}$ but the nature evils themselves are indirectly results of human fall into sin. Romans 8:19-21 implicitly suggests this view when it describes, "For the creation waits with eager longing for the revealing of the sons of God. For the creation was subjected to futility, not willingly, but because of him who subjected it, in hope that the creation itself will be set free from its bondage to corruption and obtain the freedom of the glory of the children of God." 80 Thus, according to Christians, all evils - nature evils and moral evils - in this world do not come from God which is infinite and perfect, and also they are not māya (illusion) which is a result of ignorance, but they exist because the existence of sin, namely, a rebellion of the moral creatures (e.g. mankind) against God. Through this doctrine, the question regarding the origin of the existence of evil in the world as well as its

\footnotetext{
76 King James Version.

77 Cf. Berkhof, Systematic Theology, 231. Here Berkhof uses the term physical evil to denote nature evil.

$78 \quad$ Ibid., 231.

79 Ibid.

80 English Standard Version.
} 
weaknesses has adequate answers.

As a conclusion, how the infinite becomes finite? The Christian answers are: First, this question is not relevant to the Christianity because Christian doctrine never speaks about the infinite becomes finite. There is an absolute difference between God and the world and both cannot be mixed. Second, the infinite God, in his good will, loves to create (see Genesis 1-2), and on this Psalm 104:31 describes, "May the glory of the LORD endure forever; may the LORD rejoice in his works." ${ }^{81}$ The result of God's creational act is the existence of the limited creatures. Third, moral creatures have fallen into sin and therefore they become perverse and are against God's order and law, and the results are evil, weaknesses, and finally death. At least, these doctrines leave a lesser difficulty than Shankara's doctrine of non-duality which has a bigger complication to answer the problem concerning the relation between the infinite and the finite.

\section{Logical problem}

The logical problem of Shankara's non-duality is also considerable. If the ultimate reality (Brahman) has no distinction in itself, logic has no ground to be applied (or to be operated). Indeed, in order to be applied, logic demands two conditions, namely, the existence of distinction between objects, and the existence of consciousness between subject and object. To elaborate this: First, logic can be applied at least by the existence of the distinction between A and non-A. For example, if the universe is just water and no other things than water, the difference between water and non-water cannot exist and the result is that the function of logic will be collapse. To put it another way, logic cannot be operated in a merely single entity or a pure unity or oneness. In this sense, logic is an ability to distinguish different things or objects, and confusing two or more different things is a contradiction. For instance, speaking that a dog is identical with an elephant is a contradiction (a

\footnotetext{
81 King James Version.
} 
logical fallacy). ${ }^{82}$ Hence, the Brahman of Shankara which has no distinction must be a blank entity and consequently cannot become the basis of the operation of logic.

Second, the application of logic also depends on consciousness between subject and object. Consciousness needs object (objects) to be realized or to be thought or to be conscious of. Shedd is correct when he describes that the existence of all consciousness must demand the existence of subject and object. He argues:

All consciousness implies of subject and object: a subject to know and an object to be known. If there be a subject but no object, consciousness is impossible. And if there be an object but no subject, there can be no consciousness. Mere singleness is fatal to consciousnes. I cannot be conscious of a thing unless there is a thing to be conscious of. Take away all object of thought, and I cannot think. ${ }^{83}$

In Shankara's concept of Brahman as a pure consciousness which has no objects, how does this consciousness could think or contemplate? Without at least an object or a thing or a person to be contemplated or to be thought, the consciousness is merely a blank entity. Thus, in such consciousness logic becomes collapse.

The doctrine of the Trinity is apparently the most satifiying explanation on how logic has its ground to be applied. In the Trinity which is a unity and diversity, the distinction among the three persons makes logic has its basis to be operated. The Father has his own personality which is different with the other persons, and therefore we can say that the Father is not the Son, the Son is not the Holy Spirit, and the Holy Spirit is not the Father, etc. In this way, logic could be implemented. Moreover, the consciousness of a certain Person in the Trinity has objects (the other Persons) to be thought or to be

82 Cf. Aristotle, "Metaphysics, Book IV," in The Complete Works of Aristotle Vol. II, trans. W.

D. Ross, ed. Jonathan Barnes (Princeton: Princeton University Press, 1991), Kindle Electronic Edition, 46. For instance, Aristotle argues, "the same attribute cannot at the same time belong and not belong to the same subject in the same respect," or "obviously it is impossible for the same man at the same time to believe the same thing to be and not to be." 83 William G.T. Shedd, Dogmatic Theology (Phillipsburg: P\&R, 2003), 169. 
contemplated, and consequently consciousness in the Trinity is really a life consciousness. In this life consciousness, the application of logic is intelligible.

The same principle of the operation of logic performed by God in his creational act. The Bible describes that God created distinctions, for instance, between day and night (Genesis 1:4-5), land and sea (vs. 9-10), the sun for the day and the moon for the night (vs. 16-18), each of the vegetations were created after their own kinds (vs. 11-12). This principle also applys to the living creatures which were created according to their own kinds (24-25). In this sense, it is a logical fallacy to say that a horse is a pig or an apple tree is identical with a monkey. Here the law of logic is affirmed. In the realm of mankind, God states a difference between male and female, and therefore to say that Caleb is a male and a female at the same time and definition is a logical contradiction.

Additionally, Shankara himself, as has been described in Deepak Chopra's book "God: A Story of Revelation," utilizing debates in propagating his idea and indeed he maintained antithesis (law of noncontradiction). Hence, if his opponents lost in a debate, such as happened to a man called Mandana (Suresvara), they had to submit to his teaching and became his followers. ${ }^{84}$ Indeed, his idea of Brahman as a pure single consciousness without plurality cannot become the basis of the aplication of the antithesis because antithesis demands two contrasts such as I and you, heaven and earth, live and death, short and long, etc. To put it another way, the idea of Brahman cannot become the basis of the implementation of the law of non-contradiction, and thus, in the level of metaphysic and epistemology, Shankara has no ultimate point of reference to justify his using of antithesis. On the contrary, the Christian doctrine of the Trinity really becomes the basis of the implementation of the law of logic for within the Trinity we find distinctions, and therefore we really have an ultimate point of reference for utilizing antithesis in

\footnotetext{
84 Cf. Deepak Chopra, God: A Story of Revelation (Toronto: Harper Collins, 2012) Kindle Electronic Edition: Chapter 4, Location 155-189.
} 
discourse, debate, and competing with other worldviews.

\section{Moral or ethical problem}

In the Brahman of Shankara which is a pure consciousness without distinctions, the existence of good and evil cannot become two opposite things. Consequently, moral cannot be established and its values will be meaningless. To define moral and to understand its values, three aspects must be presupposed: 1) the distinction between good and evil, 2) the existence of moral law which determines good and evil, 3) a personal God; the creator of the moral law who will be the judge. ${ }^{85}$ None of these aspects exist in the Brahman of Shankara. Thus, in the level of the ultimate reality, people cannot speak about the existence of good and evil as opposite realities because they are non-difference.

However, Shankara acknowledges the existence of good and evil in the phenomena world. He says that all ethical goods are relative and for him the only absolute good is the self realization. Furthermore, he affirms that the ethical good is what helps the realization of the infinite whereas the ethical bad is what do not help the realization. Also, he describes that whatever leads to a better future existence is good and the opposite is bad. 86 No doubt, here Shankara recognizes good and evil that exist in the phenomena world which is māy $\bar{a}$ (illusion). The problem is, how does he maintain the significance of doing good thing as good and doing evil thing as evil if these distinctions are just an illusion?

Indeed, Christian faith does not need to involve in this moral complicated problem because the Bible acknowledges the existence of a personal God who determines good and evil (cf. Genesis 2:9, 17) and therefore becomes the basis of the moral law. Also, this God becomes the Judge (cf. Isaiah 33:22; 66:16; Psalm 75:7 etc.). In this respect, God is the only absolute standard of moral. Van Til expresses this as follows:

\footnotetext{
85 Ravi Zacharias mentions these three aspect when he argues against the absurdity of the atheists who maintain the existence of evil yet reject the existence of God and his moral law. See Ravi Zacharias, Can Man Live without God [Dapatkah Manusia Hidup tanpa Allah] (Batam: Interaksara, 1999), 257.

86 Radhakrishnan, Indian Philosophy, Vol. 2, 573-4.
} 
As God is absolute rationality so God is also absolute will. By this we mean primarily that God did not have to become good, but has from everlasting to everlasting been good. In God there is no problem of activity and passivity. In God there is eternal accomplishment. God is finally and ultimately self-determinative. God is finally and absolutely necessary and therefore absolutely free. ${ }^{87}$

Genesis 2 probably can be a good example on how moral is established. Verses 8 and 9 describes, "Now the LORD God had planted a garden in the east, in Eden; and there he put the man he had formed. The LORD God made all kinds of trees grow out of the ground-trees that were pleasing to the eye and good for food. In the middle of the garden were the tree of life and the tree of the knowledge of good and evil." 88 Here God put himself as the Creator of man and the decision maker of good and evil. Verse 16 says, "And the LORD God commanded the man, 'You are free to eat from any tree in the garden; but you must not eat from the tree of the knowledge of good and evil, for when you eat from it you will certainly die.'"89 In this verse, God places himself as the judge. Consequently, Christian faith teaches that, 1) God creates man, 2) he makes a clear distinction between good and evil, 3) God sets moral law which determines good and evil, 4) God is the judge of the life of the moral creatures (e.g. mankind). Hence, Christian faith has all the aspects which are demanded for the existence of the morality which cannot exist in Shankara's concept of Brahman.

\section{The Idea of Māyā}

Shankara's idea of māya has risen many objections even from within Hindu philosophers such as Yāmunācārya, Vijñānabhiksu, and Rāmānuja. Vijñānabhiksu, for instance, argues "There is not a single Brahmasūtra in which our bondage is declared to be due to mere ignorance. As to the novel theory of $m \bar{a} y \bar{a}$ propounded by persons calling

\footnotetext{
87 Cornelius Van Till, Christian Theistic Ethics: Volume 3 of the series In Defense of Biblical Christianity (Phillipsburg: P\&R, 1980) Kindle Electronic Edition, Location 29.

88 New International Version.

89 Ibid.
} 
themselves Vedāntists, it is only a species of the subjective idealism (of the Buddhists). That theory is not a tenet of the Vedānta."90 Ramanuja expresses a similar objection when he argues that if the scriptures are unreal, even so is the Brahman of which they relate. ${ }^{91}$

Ravi Zacharias, a Christian apologist, illustrates the absurdity of the doctrine of $m \bar{a} y \bar{a}$ when he speaking a humorous story about Shankara in his book. It is said that Shankara had just finished lecturing the king on the deception of the mind and the material reality. However, the next day, the king let an elephant chasing Shankara and the philosopher finding safety by running up a tree. Afterwards, the king asked him why he run up if the elephant was unreal. Shankara deftly responded that what the king saw was a non-real Shankara who climbing a non-real tree.92 On Shankara's response, Zacharias argues that one can say that Shankara's answer is also a non-real answer. ${ }^{93}$ It is clearly shown here that Shankara's doctrine of māya has a self-contradictory element. If all things are non-real, then the teachings of Shankara on Brahman and māya must be also non-real. Thus, why people have to learn or listen those non-real teachings?

The doctrine of creation in the Bible teaches that God created real things; real universe, real man and woman, real trees, real living creatures etc. The opening line of the Bible, "In the beginning God created the heavens and the earth"94 (Genesis 1:1) maintains the fact that God created a real universe. The subsequent verses describe the process of creation in a detail and empirical way, for instance, it speaks about water, land, vegetation, animals, etc. Moreover, those verses denote the days of creation in a very literal manner. No room for the doctrine of $m \bar{a} y \bar{a}$ in the Scripture. Even when the Bible describes the human nature of

\footnotetext{
90 Radhakrishnan, Indian Philosophy, Vol. 2, 438.

91 Ibid., 638.

92 Ravi Zacharias, Jesus among Other Gods: The Absolute Claims of the Christian Message (Nashville: Thomas Nelson, 2000), 119.

93 Ibid.

94 New International Version.
} 
Christ, particularly his body, it is not just a māya body, it is real. That is why, when the disciples were afraid lest they saw a ghost (Matthew 14:26), Jesus assured them that he is real. He said, "Take courage! It is I. Don't be afraid" 95 (v. 27). The significance of this doctrine is fundamental. If creation is real and hence human fall into sin is real, then the Christian hope, faith, and love are also real. Believing that all is nonreal will lead to a nihilistic view which sees everything as meaningless because they are non-real. Zacharias is correct when he maintains the realness of Jesus's teaching:

I am persuaded that the whole teaching of Jesus stands unique in all of the world's religions. I am persuaded that his analysis of the human condition is the most real and empirically verifiable. I am also certain that if we fail to come to terms with what he said and taught, we will put all of humanity at risk. ${ }^{96}$

\section{Conclusion}

The study finds some complicated problems in Shankara's theory of non-duality. Concerning the concept of Brahman-Ātman, there are metaphysical problems (e.g. how the infinite becomes finite), logical problems (e.g. how the law of logic can be applied if all is the same), and ethical problems (e.g. if all is one, there is no difference between good and evil). Thus, we can conclude that the Christian teaching that acknowledges God and the world as have absolute difference is more reasonable. Furthermore, the idea of māy $\bar{a}$ (illusion) also has significant problem, for instance, if the phenomena world is just an illusion, it means that the teaching on illusion itself is also an illusion and consequently we have no obligation to pay attention to that illusion. On the contrary, the Christian faith maintains that the world as God's creation is a real world and hence we can find meaning and values in it.

95 Ibid.

96 Ravi Zacharias, Why Jesus: Rediscovering His Truth in an Age of Mass Marketed Spirituality (New York: Faith Words, 2012) Kindle Electronic Edition: Chapter 3 Location 108. 